\title{
Causal Relationship of Wastewater Management and Morbidity of Diseases Related to Wastewater in Colombia
}

\section{Juan Pablo Rodríguez Miranda*}

Faculty of Environment and Natural Resources, Universidad Distrital Francisco José de Caldas, Colombia

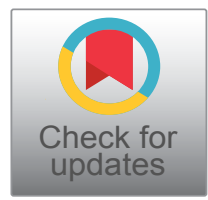

*Corresponding author: Juan Pablo Rodríguez Miranda, Professor Titular, Faculty of Environment and Natural Resources, Universidad Distrital Francisco José de Caldas, Carrera 5 Este No 15 - 82, Avenida Circunvalar, Venado de Oro, Bogotá DC, Colombia

The causal relationship between environmental pollution and specifically the lack of adequate environmental sanitation, in the context of the elimination of excreta and solid waste disposition on site guaranteed for this purpose, conceives a high risk in the proliferation of vectors and therefore proportional generation morbidity in diseases of a hydric nature that directly or indirectly affects the population.

According to the above, the most common affectations in the tropical area, due to the lack of environmental sanitation, can be mentioned, $37.1 \%$ respiratory infections, $8.6 \%$ diarrhea, $5.7 \%$ intestinal parasitism, $8.6 \%$ skin problems (dermatological) and $40 \%$ other diseases [1].

Specifically in Latin America, diseases transmitted by untreated or contaminated water, are usually produced by bacteria, viruses, protozoa and helminths, which in turn cause typhoid fever, cholera, diarrhea, hepatitis, amoebic dysentery, among other causes of diseases, where $13 \%$ of the population was exposed to untreated water or with signs of contamination, where $94 \%$ of the cases due to diarrhea were due to poor drinking water quality $[2,3]$.

In Colombia, reported cases of acute diarrheal disease indicate that $17.5 \%$ were due to Rotavirus, Giardia duodenalis, Cryptosporidium sp, Shigella sp and Salmonella $s p$ and this has a causal relationship among other reasons as the lack of water availability (quantity and quality) and according to the level of risk, $13.22 \%$ of the Colombian population presents a high and very high risk in the quality of drinking water [4], in addition to the low treatment capacity of $21 \%$ with flow rates of
$39.6 \mathrm{~m}^{3} / \mathrm{s}$ of acceptable treatment [5] and the rest of the amount of wastewater generated, is discharged to a body of water or for irrigation, these conditions being highly vulnerable to pollution of the water resource and, therefore, a vehicle of transmission of diseases.

In conditions of Latin America and the Caribbean, especially in Colombia, is the investment in sanitation systems (potable water supply, adequate disposal of ordinary solid waste and wastewater treatment), to increase the quality of life, increase structural health scenarios environmental and optimal operation of sanitation systems, in order to reduce costs in remediation due to water-related diseases, improvement of labor productivity conditions of the population and a notable reduction in the associated morbidity and mortality rates to diseases intestinal infections related to water quality.

\section{References}

1. Minambiente (2012) Diagnostico Nacional de Salud Ambiental. Ministerio de Ambiente y Desarrollo Sostenible, Bogotá, Colombia.

2. World Health Organization (WHO), (2009) Global health risks: Mortality and burden of disease attributable to selected major risks. WHO Press, Geneva.

3. Hatt LE, Waters HR (2006) Determinants of child morbidity in Latin America: A pooled analysis of interactions between parental education and economics status. Soc Sci Med 62: 375-386.

4. INS (2012) Estado de la vigilancia de la calidad de agua para consumo humano en Colombia 2007 - 2011. Instituto Nacional de Salud, Bogotá, Colombia.

5. SSPD (2013) Informe técnico sobre sistemas de tratamiento de aguas residuales en Colombia. Superintendencia de servicios publicos domiciliarios, Bogotá. 